\title{
ГЕНДЕРНЫЕ РАЗЛИЧИЯ КАРДИОМЕТАБОЛИЧЕСКИХ НАРУШЕНИЙ В МОЛОДОМ ВОЗРАСТЕ
}

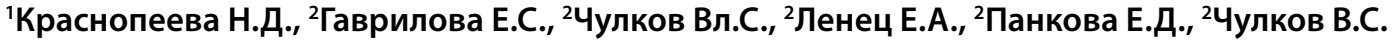 \\ ${ }^{1}$ НУЗ «Дорожная клиническая больнича на ст. Челябинск ОАО «Российские железные дороги» \\ 2 ФГБОУ ВО «Южно-Уральский государственный медицинский университет» Минздрава России, Челябинск
}

ЦЕЛЬ: провести сравнительную оценку кардиометаболических нарушений в гендерном аспекте у лиц молодого возраста.

МАТЕРИАЛЫ И МЕТОДЫ: тип исследования: поперечный срез («cross-sectional study»). В исследование вошли 251 пациент амбулаторного звена, обратившихся в поликлинику ГКБ № 11 г. Челябинска за период 2013-2016 гг. Критерии включения: возраст 18-44 лет, согласие на участие в исследовании. Критерии исключения: симптоматические артериальные гипертензии (АГ), ассоциированные клинические состояния, сахарный диабет 1 и 2 типа. Все пациенты разделены на 2 группы: группа $1-124$ мужчины, 27 [21-36] лет; группа $2-127$ женщин 35 [26-41] лет. Определяли уровни общего холестерина, XС-ЛПНП, ХС-ЛПВП, триглицеридов, глюкозы и инсулина с расчетом индекса HOMA-IR, лептина, адипонектина, интерлейкина-1ß (IL-1ß) и интерлейкина-6 (IL-6), фактора некроза опухолей-a (TNF-a), эндотелина и ангиотензина II, фибриногена и ингибитора активатора плазминогена типа 1 (PAl-1) натощак в сыворотке крови методом ИФА. Использовался пакет статистических программ MedCalc (Бельгия, 2019) с применением U-критерия Манна-Уитни, хи-квадрата Пирсона, критерия Фишера, критерия Спирмена. Данные в тексте представлены M \pm SD и Me [Q25-Q75]. Для всех видов анализа статистически достоверными считались значения $\mathrm{p}<0,05$.

РЕЗУЛЬТАТЫ: частота традиционных факторов кардиоваскулярного риска (АГ, абдоминальное ожирение, отягощенная наследственность по АГ) была сопоставимой. Средние показатели индекса массы тела (ИМТ), систолического и диастолического артериального давления в группах не отличались. Наиболее значимые различия у женщин были получены при сравнении концентраций лептина $(34,6$ [13,8-49,1] vs $15,5[4,4-16,2]$ нг/л, p<0,001), адипонектина $(8,9[7,5-11,7]$ vs 7,9 [4,9-10,0] мкг/мл, $p=0,01)$ и фибриногена $(3,9[3,4-4,5]$ vs $3,4[2,8-4,0], p<0,001)$ г/л. В то же время, среди мужчин выявлены достоверно более высокие концентрации ангиотензина II (9,1 [6,4-24,4] vs 8,5 [5,0-15,5] нг/мл, p=0,04), ингибитора активатора плазминогена 1 типа (PAl-1) (399,7 [264,1-597,9] vs 342,3 [221,9-453,5] нг/мл, p=0,02) и IL-10 (6,3 [5,7-6,9] vs 5,2 [4,1-5,5] пг/мл, p=0,03). У мужчин концентрация лептина имела положительные корреляционные связи с ИМТ ( $r=0,65 ; p<0,001)$, фибриногеном $(r=0,47 ; p<0,001)$ и отрицательные - c IL-10 $(r=-0,82 ; p<0,001)$. У женщин концентрация лептина имела положительные корреляционные связи с ИМТ $(r=0,80 ; p<0,001)$, PAI-1 $(r=0,52 ; p<0,001)$ и отрицательные - c TNF-a $(r=-0,47 ; p<0,001)$.

\section{ВЫводЫ:}

1. При проведении сравнительной оценки кардиометаболических нарушений среди молодых мужчин и женщин выявлены гендерные особенности: среди женщин обнаружены более высокие концентрации лептина, адипонектина и фибриногена, а среди мужчин - более высокие концентрации ангиотензина II, ингибитора активатора плазминогена 1 типа и интерлейкина-10 в сыворотке крови.

2. При проведении линейного корреляционного анализа у мужчин молодого возраста концентрация лептина имела положительные корреляционные связи с индексом массы тела, фибриногеном и отрицательные корреляционные связи с интерлейкином-10; у женщин концентрация лептина имела положительные корреляционные связи с индексом массы тела, ингибитора активатора плазминогена 1 типа и отрицательные корреляционные связи с фактором некроза опухолей-а.

КЛЮЧЕВЫЕ СЛОВА: кардиометаболические нарушения, артериальная гипертензия, абдоминальное ожирение, гендерные различия, молодой возраст. 